\title{
Evaluation of EU legislation on blood: a bioethical point of view
}

This article was published in the following Dove Press journal:

Journal of Blood Medicine

9 November 2017

Number of times this article has been viewed

\section{Carlo Petrini \\ Bioethics Unit, Office of the President, National Institute of Health, Rome, Italy}

Correspondence: Carlo Petrini Bioethics Unit, Office of the President, National Institute of Health, Via Giano della Bella 34, I-00I62 Rome, Italy Tel +390649904021

Fax + 390649904303

Email carlo.petrini@iss.it
Abstract: A review of the European Union (EU) regulations concerning blood, tissues, and cells of human origin is under way in the EU. From the ethical point of view, the non-remuneration of donations and the ban on deriving gain from human biological materials are of particular significance. While the basic ethical principles involved in the procurement, preservation, and use of these materials are the same, their practical application should be adapted to the specific context of each material. In the case of donation and use of blood, in particular, the issue of legitimate reimbursements to donors and for transfusion centers has to be managed in accordance with the principle of non-commercialization. There is also a need for strict rules to avoid possible commercial spillover effects from blood-derived products. The author proposes ethical criteria regarding reimbursements to donors, costs associated with processing, and the development (and possible marketing) of products.

Keywords: bioethics, blood, legislation, Europe, transfusion

\section{Introduction}

The European Commission has begun the process of evaluating European Union (EU) legislation ${ }^{1}$ concerning blood, tissues, and cells of human origin, in particular Directives 2002/98/EC ${ }^{2}$ and 2004/23/EC, ${ }^{3}$ together with the subsequent implementing technical directives (Directives 2004/33/EC ${ }^{4}$ as amended, 2005/61/EC, ${ }^{5}$ 2005/62/EC, ${ }^{6}$ 2006/17/EC ${ }^{7}$ as amended, 2006/86/EC ${ }^{8}$ as amended, and Directive (EU) 2015/566 ${ }^{9}$.

This paper offers a few comments concerning some of the ethical aspects of Directive 2002/98/EC on human blood and blood components.

\section{Preliminary remarks}

Two basic assumptions seem opportune:

1. According to the roadmap proposed by the EU, "aspects which fall within the competence of Member States, such as clinical application and ethical decisions, are not covered by this evaluation." ${ }^{1}$ However, the scientific and technical aspects cannot be treated separately from those of an ethical nature, and the ethical importance of the requisites set down in Directive 2002/98/EC cannot be ignored. The following are some of the requisites with clear ethical implications:

- the need for adequate measures to encourage voluntary unpaid blood donations;

- the requirement that prospective blood donors be given appropriate information, such as the details of the procedure involved and the opportunity to change their 
minds, as well as the need to provide personal data, such as their medical histories;

- the need for blood to be collected and tested only by designated authorized, accredited or licensed establishments with suitably qualified personnel;

- the need for establishments to have quality systems in place;

- the need for blood and blood components to be traceable from donor to recipient and vice versa and for the data to be kept for at least 30 years;

- the requirement that any serious adverse events arising from accidents or errors be notified to the competent authority;

- the requirement that the data collected, including genetic information, be rendered anonymous so that the donor cannot be identified;

- the need for blood establishments to evaluate all blood donors, test each donation and ensure proper storage, transportation, and distribution of the donated blood.

2. The EU is also in the process of updating Directives on biomedical matters issued between the end of the last century and the beginning of this century. Clinical trials, for instance, are now covered by Regulation 536/2014 ${ }^{10}$ and medical devices by Regulations $745 / 2017^{11}$ and $746 / 2017,{ }^{12}$ all of which amend and replace the earlier Directives. This itself is significant, since Regulations, unlike Directives, are immediately applicable in individual states, thus removing the flexibility previously allowed to member states in regard to the transposing of Directives.

\section{General considerations}

A comprehensive assessment of EU legislation on blood, tissues, and cells ${ }^{1}$ of human origin involves a multitude of questions. The roadmap for this evaluation process groups the issues into the following categories: relevance, effectiveness, efficiency, coherence, added value.

The following examples of ethical issues involved in the different categories are by no means exhaustive:

\section{Relevance}

- The solidity of the entire regulatory framework requires that all the rules on blood, cells, and tissues be based on the same ethical values and principles. The implementation of these values and principles will then have to be applied to specific circumstances and adapted in accordance with the type of biological material involved. In particular, because blood can be donated repeatedly, there are peculiar aspects of blood donation that do not apply with other types of human biological material. In adapting rules to specific cases, however, no concessions should be allowed where common principles are at stake.

\section{Effectiveness}

- The question of safety for donors (as well, obviously, as for recipients) deserves special attention.

- The emergence of new infectious diseases could make additional tests necessary for donors.

- The introduction of modern marketing techniques to attract and retain donors and the creation of sophisticated donor databases, to ensure that a sufficient number of donors enter into relationships with their blood establishments, should not be allowed to become a form of pressure that induces feelings of guilt in individuals who do not wish to donate or who cease donating. Another aspect requiring attention is the costs and sources of financing for such marketing techniques, as well as what form they should take.

\section{Efficiency}

- Demographic changes such as the increasing age of populations and the fall in births, as well as the impact of migration, will lead to changes in both the supply of and the demand for blood, which must be borne in mind.

\section{Coherence}

- The Directive focuses mainly on the product, though it might be appropriate to focus more on patients and donors, while also bearing in mind the development of the "Patient Blood Management" approach.

- In the interests of consistency with other legislation, it would be useful to encourage greater clarity regarding the classification and regulation of biological products obtained from human blood, particularly blood components not for use in transfusions.

- The regulations regarding blood, tissues, and cells should be in line with those applying to trials of Advanced Therapy Medicinal Products (ATMPs).

- There are some inconsistencies within member states regarding the status of blood products. Blood and blood components were added to the 18 th core list of the World Health Organization (WHO) Model List of Essential Medicines (EMs) in 2013. ${ }^{13}$ EMs are those that satisfy the priority healthcare needs of the population. The list is especially important as it is frequently taken as the basis for decisions in matters of healthcare policy and resource 
allocation, as well as in questions of investments concerning the governance of blood systems in particular.

\section{Added value}

- The Directives were responsible for harmonizing the blood transfusion schemes in member states and helped to achieve overall self-sufficiency within the EU. The transposition of Directives into national legislation created EU-wide uniformity. At the regional level, an inter-regional imbalance in the quantity of norms and regulations can lead to fragmentation, with potentially harmful effects on the drive toward harmonization.

\section{Non-remuneration and the ban on financial gain}

Non-remuneration and the ban on financial gain are two discrete concepts: the former applies to individuals and the latter to states and organizations. They are, however, closely related, given that both derive from the principle asserted in numerous documents, including the Oviedo Convention. The 20th anniversary of the Oviedo Convention represents an opportunity to extend the horizon of the EU to the 47 Council of Europe member states. Article 21 of the Convention states that: "The human body and its parts shall not, as such, give rise to financial gain." ${ }^{14}$ The Convention is recognized as an authoritative text, even though it has not yet been ratified by all the member states of the Council of Europe. ${ }^{15}$ Italy has ratified the Convention but to date has not deposited the relevant legislation with the Council, ${ }^{16}$ and it is therefore not formally binding.

The principle of non-remuneration is also cited in other Council of Europe documents, such as the Recommendation 95-15, which states that "The donation of blood, plasma, or cellular components should comply with the ethical principle of voluntary, non-remunerated donation applicable to all removal, grafting and transplantation of human substances."

Other respected institutions have also unequivocally recognized these two principles of non-remuneration and the ban on financial gain. The WHO, for instance, has made several pronouncements on the subject, including the Melbourne Declaration $^{18}$ and the Rome Declaration. ${ }^{19}$ Article 3 of the EU Charter of Fundamental Rights affirms "the prohibition on making the human body and its parts as such a source of financial gain." ${ }^{20}$

The periodic reports published by the EU Commission provide an overview of the situation in Europe regarding the non-remuneration of blood donations. The most recent report ${ }^{21}$ notes that in almost every country, donation promotion activities are the main actions taken to increase supply.
Although in the large majority of countries, the principle of voluntary unpaid donation (VUD) is mandatory at national level, the relevant legislations often refer to an "encouragement" or to a "strong recommendation." The practical application of the VUD principle varies across the Union: certain practices are perceived as compensation in 1 country and as incentives in another. According to the report, "(i)t is common practice to provide refreshments to donors and to give them small tokens such as pin badges, pens, towels, t-shirts and mugs." ${ }^{21}$ Moreover, in many member states "donors have their travel costs reimbursed and get time off work in the public and private sector." ${ }^{21} \mathrm{~A}$ few states give donors a fixed payment that is not directly related to actual costs incurred. Only a few states have national guiding principles to define what form of compensation or other practice is allowed and under which circumstances.

In the report "Human bodies: donation for medicine and research," the Nuffield Council ${ }^{22}$ proposed a "ladder" with six levels of intervention to encourage donations. The lower four rungs of the ladder are "altruistic" interventions, while the top two rungs are "non-altruistic-focused." According to the report (which sparked considerable controversy ${ }^{23}$ ) where a healthcare need cannot be satisfied through altruistic interventions, the possibility of non-altruistic-focused interventions should be considered. ${ }^{22}$

There can be no question that it is not only legitimate, but also proper to reimburse any costs incurred by donors (eg, as recognized in Article 1 of the Code of Ethics for Blood Donation and Transfusion of the International Society of Blood Transfusion ${ }^{24}$ ) as well as by institutions (as acknowledged, for instance, in the 5th of the World Health Organization's Guiding Principles on Human Cell, Tissue and Organ Transplantation ${ }^{25}$ ).

According to Farurgia and Del Bo "there are certain contradictions between the principle of non-commercialisation, the enormous movements of money inevitably involved in centralised blood systems, and the need to make the most of the system (...). (F)rom the ethical point of view these contradictions could be at least partially mitigated. ${ }^{26}$ Their reflections clearly aim to legitimize the collection of paid plasma and the activities of the wider commercial industry within the ISBT Code. The authors argue for a paradigm shift whereby the patient is placed at the center of all decisions and processes. However, "the proposed approach fails to recognise the unique aspect of donation whereby one individual provides for another with no direct personal benefit." ${ }^{27}$

The well-being of the numerous patients who could or do benefit from plasma-derived medicinal products (PDMPs) 
deserves particular attention. Currently, almost $70 \%$ of the plasma from which PDMPs are derived is provided by donors who receive monetary compensation, while a large number of patients worldwide have no, or at best suboptimal, access to these products. Some authors have suggested it is time to re-think whether an absolutist position against compensation is still relevant or would be judged appropriate if it were evaluated using a risk-based decision-making approach. ${ }^{28}$

It must be recognized that transfusions and transplants involve substantial flows of money: it is estimated that the annual spending throughout the EU on blood, tissues, and cells amounts to 6 billion euros, with another 3 billion euros on bone marrow transplants, while the market value of plasma-derived products is estimated at 4 billion euros. ${ }^{1}$

In view of the above, it is useful to identify a few criteria that should be clearly articulated during the review of the Directive:

\section{With regard to donors}

- The human body and its parts must never, in any circumstances, give rise to financial gain. The donation of blood must be voluntary and should not be associated with any form of payment.

- The notion of "non-remuneration" does not exclude the possibility of offering legitimate "reimbursements" to donors. A clear and impassable red line must be established between legitimate forms of reimbursement (for expenses incurred or loss of earnings) for donors and any benefit of whatever nature (not only financial) associated with the donation. Reimbursements should be limited strictly to actual costs incurred or earnings lost and directly associated with the donation.

- The possibility of compensation for possible damages directly attributable to a donation should be allowed.

- No form of compensation for any inconvenience associated with a donation is admissible, as this could conceal the recruitment of "volunteers" and, consequently, the exploitation of vulnerable groups of individuals.

- The offer of favorable rates to donors for healthcare services not associated with donations is not admissible.

- No types of incentive/reimbursement should be perceivable as concealing forms of payment; they should therefore not have a cash value and not be transferable.

\section{With regard to the costs associated with procedures}

- The process of donation calls for recourse to professional personnel and appropriate procedures. Both the aspects should be carefully regulated and paid for at a fair price. The legitimate costs associated with procurement and other activities necessary to guarantee the safety, quality, and efficacy of the materials used should be properly covered.

- Costs associated with the storage and, where appropriate, processing (chiefly in the case of cells and tissues) of materials should be met by the end user institutions.

- The professionals involved in these procedures (whether in public or private institutions) should not derive any benefit directly from their participation.

Another aspect involved is that of the possible marketing of products derived from voluntary blood donations. The Belgian Superior Health Council ${ }^{29}$ noted in its comments on the draft for the road map ${ }^{1}$ that the existence of flows of money verging on trade cannot be denied. Concern has also been expressed by the Belgian Federal Agency of Medicines and Health Products ${ }^{30}$ and other institutions.

The problem also arises in a similar manner in the field of biotechnology, where regulations apply from the moment a patent is granted. The Organization for Economic Cooperation and Development, for instance, recognizes in the "Guidelines for the licensing of genetic inventions" that "License agreements should define the roles and responsibilities of the parties in the commercialisation, if any, of the products and services arising from the use of the licensed genetic invention." 31

It must be acknowledged that, as a general rule, blood, in common with other materials of human origin (eg, bone parts removed during surgery) can be used to derive products with a marketable value. Even though the donor may no longer be identifiable, the origin of the material is still an act of voluntary generosity. Elements or products derived from the human body should therefore be used only for therapeutic purposes or for biomedical research: their for-profit use by the (non-medically driven) cosmetics industry should not be allowed. In addition, in the event that the use of human biological material generates some form of financial gain, this should be used principally to benefit the community at large (national health services).

Nonetheless, there may be occasions when commercial spillover effects cannot be excluded. The development of therapeutically effective products from donated human biological material that is unusable and therefore destined to be discarded satisfies two of the basic principles of bioethics: 1) beneficence (therapeutic principle), which recognizes that medicine is essentially a matter of therapy, in other words, its aim is to defend and promote health; and 2) justice, which is rooted in sociality and encourages the expression of medicine 
as a service intended for the general good. Such a product is cord blood that is unsuitable for transplantation but which can be used to produce platelet gel ${ }^{32}$ and other products ${ }^{33}$ with considerable therapeutic potential.

The possibility that products derived from donated human biological materials may enter commercial circuits is not excluded, for example, by the Council on Ethical and Judicial Affairs of the American Medical Association in its Code of Medical Ethics ${ }^{34}$ and in the document "Who should profit from the economic value of human tissue? An ethical analysis." ${ }^{35}$ In such circumstances, the Council on Ethical and Judicial Affairs calls for the mandatory compliance with specific requisites, including, among others, information and consent, possibility for patients to share in the profit, absolute guarantee that good clinical practice is in no way influenced by commercial objectives.

\section{Conclusion}

During revision of the Directives, as well as in additional texts that will be published in the future, the following ethical criteria should always be reasserted and applied:

- consent to donation should always be given in total freedom and in full compliance with current legislation;

- the rules regarding fixed costs, compensation, and reimbursements should be addressed in EU Directives and applied uniformly in all member states;

- legislators and national authorities should encourage a culture of donation aimed at spreading awareness that numerous lives can be saved by a simple altruistic gesture;

- some of the states that are signatories to declarations of principle regarding the non-remuneration of donations such as those mentioned above however provide for forms of reimbursement that more or less explicitly amount to payments. In these cases, the term "donation" should no longer be used, for the sake of consistency; if an action is remunerated, it is not a donation;

- the possibility of establishing partnerships between the public and private sectors for the marketing of therapeutic products outside national healthcare services could be explored.

\section{Acknowledgments}

The author is very grateful to Dr Luciana Riva who provided helpful comments and suggestions.

The present article is based partly on an invited lecture that the author gave at the "Evaluation of EU legislation on blood: the Italian roadmap" workshop organized by the Italian National Blood Centre in Rome.

\section{Disclosure}

The author reports no conflicts of interest in this work.

\section{References}

1. European Commission. Evaluation and fitness check (FC) roadmap. Evaluation of Union legislation on blood, tissues and cells. 2017. Available from: http://ec.europa.eu/smart-regulation/roadmaps/docs/ plan_2016_154_evaluation_eu_legislation_on_blood_en.pdf. Accessed August 6, 2017.

2. European Parliament, Council of the European Union. Directive 2002/98/EC of the European Parliament and of the Council of 27 January 2003 setting standards of quality and safety for the collection, testing, processing, storage and distribution of human blood and blood components and amending Directive 2001/83/EC. Off J Eur Union. 2003;33:30-40.

3. European Parliament, Council of the European Union. Directive 2004/23/EC of the European Parliament and of the Council of 31 March 2004 on setting standards of quality and safety for the donation, procurement, testing, processing, preservation, storage and distribution of human tissues and cells. Off J Eur Union. 2004;L102:48-58.

4. European Commission. Commission Directive 2004/33/EC of 22 March 2004 implementing Directive 2002/98/EC of the European Parliament and of the Council as regards certain technical requirements for blood and blood components. Off J Eur Union. 2004;L91:25-39.

5. European Commission. Commission Directive 2005/61/EC of 30 September 2005 implementing Directive 2002/98/EC of the European Parliament and of the Council as regards traceability requirements and notification of serious adverse reactions and events. Off J Eur Union. 2006;L287M:350-358.

6. European Commission. Commission Directive 2005/62/EC of 30 September 2005 implementing Directive 2002/98/EC of the European Parliament and of the Council as regards Community standards and specifications relating to a quality system for blood establishments. Off J Eur Union. 2005;L256:41-48.

7. European Commission. Commission Directive 2006/17/EC of 8 February 2006 implementing Directive 2004/23/EC of the European Parliament and of the Council as regards certain technical requirements for the donation, procurement and testing of human tissues and cells. Off J Eur Union. 2006; L330M:162-174.

8. European Commission. Commission Directive 2006/86/EC of 24 October 2006 implementing Directive 2004/23/EC of the European Parliament and of the Council as regards traceability requirements, notification of serious adverse reactions and events and certain technical requirements for the coding, processing, preservation, storage and distribution of human tissues and cells. Off J Eur Union. 2006;L294:32-50.

9. European Commission. Commission Directive (EU) 2015/566 of 8 April 2015 implementing Directive 2004/23/EC as regards the procedures for verifying the equivalent standards of quality and safety of imported tissues and cells. Off J Eur Union. 2015; L93: 56-68.

10. European Parliament, Council of the European Union. Regulation (EU) No 536/2014 of the European Parliament and of the Council of 16 April 2014 on clinical trials on medicinal products for human use, and repealing Directive 2001/20/EC. Off J Eur Union. 2014;L158:1-76.

11. European Parliament, Council of the European Union. Regulation (EU) 2017/745 of the European Parliament and of the Council of 5 April 2017 on medical devices, amending Directive 2001/83/EC, Regulation (EC) No 178/2002 and Regulation (EC) No 1223/2009 and repealing Council Directives 90/385/EEC and 93/42/EEC. Off J Eur Union. 2017;L117:1-175.

12. European Parliament, Council of the European Union. Regulation (EU) 2017/746 of the European Parliament and of the Council of 5 April 2017 on in vitro diagnostic medical devices and repealing Directive 98/79/EC and Commission Decision 2010/227/EU. Off J Eur Union. 2017;L117:176-332. 
13. World Health Organization. WHO Model List of Essential Medicines. 2017 (current edition). Available from: http://www.who.int/medicines/ publications/essentialmedicines/en/. Accessed September 24, 2017.

14. Council of Europe. Convention for the Protection of Human Rights and Dignity of Human Being with Regards to the Application of Biology and Medicine: Convention on Human Rights and Biomedicine. Oviedo. 1997. Available from: http://www.coe.int/en/web/conventions/full-list/-/ conventions/rms/090000168007cf98. Accessed August 6, 2017.

15. Council of Europe. Chart of signatures and ratifications of Treaty 164. Available from: http://www.coe.int/en/web/conventions/full-list/-/conventions/treaty/164/signatures?p_auth $=642 \mathrm{dmJPa}$. Accessed September $18,2017$.

16. Legge 28 marzo 2001, n. 145. Ratifica ed esecuzione della Convenzione del Consiglio d'Europa per la protezione dei diritti dell'uomo e della dignità dell'essere umano riguardo all'applicazione della biologia e della medicina: Convenzione sui diritti dell'uomo e sulla biomedicina, fatta a Oviedo il 4 aprile 1997, nonché del Protocollo addizionale del 12 gennaio 1998, n. 168, sul divieto di clonazione di esseri umani. Gazzetta Ufficiale della Repubblica Italiana - Serie generale. 2001;95:6-21.

17. Council of Europe. Recommendation R(95)14 on the protection of the health of donors and recipients in the area of blood transfusion. 1995. Available from: https://www.msssi.gob.es/profesionales/saludPublica/ medicinaTransfusional/recomendaciones/docs/Rec95_14.pdf. Accessed August 6, 2017.

18. World Health Organization. The Melbourne Declaration on 100\% Voluntary Non-remunerated Donation of Blood and Blood Components. 2009. Available from: http://www.who.int/entity/worldblooddonorday/ Melbourne_Declaration_VNRBD_2009.pdf?ua=1. Accessed August 6, 2017.

19. World Health Organization. The Rome Declaration on achieving selfsufficiency in safe blood and blood products, based on voluntary nonremunerated donation (High-level Policy Makers Forum on Achieving Self-sufficiency in Safe Blood and Blood Products, based on Voluntary Non-remunerated Donation). Rome. 2013. Available from: https://www. avis.it/userfiles/file/RomeDeclarationSelf-SufficiencySafeBloodBloodProductsVNRD.pdf. Accessed August 6, 2017.

20. European Union. Charter of Fundamental Rights of the European Union. Off J Eur Union. 2000;C364:1-22.

21. European Commission. Report from the Commission to the European Parliament, the Council, the European Economic and Social Committee and the Committee of the Regions on the implementation of the Directives 2002/98/EC, 2004/33/EC, 2005/61/EC and 2005/62/EC setting standards of quality and safety for human blood and blood components. $\operatorname{COM}(2016) 224$. 2016. Available from: http://eur-lex.europa. eu/search.html?dtn=0224\&subdom_init=all_all\&dts_dom=all\&case_ law_summary=false \&type $=$ advanced\&dts_subdom=all_all\&excco nsleg=true \& typeofactstatus $=$ com_join $\&$ qid $=1498319740189 \& \mathrm{db}_{-}$ type_of_act=comjoin\&dta $=2016 \& l o c a l e=e n$. Accessed June 24, 2017.
22. Nuffield Council on Bioethics. Human bodies: donation for medicine and research. 2011. Available from: https://nuffieldbioethics.org/ wp-content/uploads/2014/07/Donation_full_report.pdf. Accessed September 23, 2017.

23. Petrini C. Production of plasma-derived medicines: ethical implications for blood donation and donors. Blood Transfus. 2014;12(Supp1 1): S389-S394.

24. International Society of Blood Transfusion (ISBT). A code of ethics for blood donation and transfusion. (Adopted by General Assembly of ISBT, July 12, 2000. Amended by the General Assembly of ISBT, September 5 , 2006). Available from: https://www.isbtweb.org/fileadmin/user_upload/ ISBT_Code_of_Ethics/Code_of_ethics_new_logo_-_feb_2011.pdf. Accessed June 24, 2017.

25. World Health Organization. Guiding Principles on human cell, tissue and organ transplantation. Resolution WHA63.22. 2010. Available from: http://www.who.int/entity/transplantation/Guiding_PrinciplesTransplantation_WHA63.22en.pdf?ua=1. Accessed June 24, 2017.

26. Farrugia A, Del Bò C. Some reflections on the Code of Ethics of the International Society of Blood Transfusion. Blood Transfus. 2015;13(4):551-558.

27. Flanagan P. The Code of Ethics of the International Society of Blood Transfusion. Blood Transfus. 2015;13(4):537-538.

28. Skinner MW, Hedlund Hoppe PA, Grabowski HG, et al. Risk-based decision making and ethical considerations in donor compensation for plasma-derived medicinal products. Transfusion. 2016; 56(811):2889-2894.

29. Superior Health Council. Roadmap evaluation and fitness check of Union regulation on blood, tissues and cells-SHC 9411.2017. Available from: http://ec.europa.eu/dgs/health_food-safety/dgs_consultations/ docs/ev_20170118_co14_en.pdf. Accessed June 24, 2017.

30. Federal Agency of Medicines and Health Products. Evaluation of Union legislation on blood, tissues and cells. 2017. Available from: http://ec.europa.eu/dgs/health_food-safety/dgs_consultations/docs/ ev_20170118_co05_en.pdf. Accessed June 24, 2017.

31. Organisation for Economic Co-operation and Development - OECD. Guidelines for the licensing of genetic inventions. 2006. Available from: http://www.oecd.org/science/biotech/guidelinesforthelicensingofgeneticinventions.htm. Accessed August 6, 2017.

32. Parazzi V, Lazzari L, Rebulla P. Platelet gel from cord blood: a novel tool for tissue engineering. Platelets. 2010;21(7):549-554.

33. Versura P, Buzzi M, Giannaccare G, et al. Cord blood serum-based eye drops: the impact of donor haematological and obstetric factors on the variability of epidermal growth factor levels. Blood Transfus. 2014;12(Suppl 1):s44-s50.

34. American Medical Association (Council on Ethical and Judicial Affairs). Code of Medical Ethics. Current Opinions with Annotations. Chicago: AMA Press; 2004: 33-34.

35. American Medical Association (Council on Ethical and Judicial Affairs). Who should profit from the economic value of human tissue? An ethical analysis. CEJA Report E-A90. Chicago: AMA Press; 1990.
Journal of Blood Medicine

\section{Publish your work in this journal}

The Journal of Blood Medicine is an international, peer-reviewed, open access, online journal publishing laboratory, experimental and clinical aspects of all aspect pertaining to blood based medicine including but not limited to: Transfusion Medicine; Blood collection, Donor issues, Transmittable diseases, and Blood banking logistics; Immunohematology; Artificial and alternative blood based therapeutics; Hematology; Biotechnology/nanotechnology of blood related medicine; Legal aspects of blood medicine; Historical perspectives. The manuscript management system is completely online and includes a very quick and fair peer-review system. Visit http://www.dovepress.com/ testimonials.php to read real quotes from published authors. 